\title{
MORAL RIGHTS OF AUTHORS - \\ AN OVERVIEW WITH SPECIAL REGARD \\ TO THE RIGHT TO INTEGRITY ${ }^{1}$
}

Sápi Edit

\section{INTRODUCTION}

Intellectual property law and the legal protection of creators, authors are very closely linked to the protection of individual and persons. According to several authors, the protection of intellectual property itself can be deduced from the protection of the individual and the rights relating to personality. ${ }^{2}$ According to the Hungarian Copyright $\mathrm{Act}^{3}$, the author is entitled to the sum of copyright (moral rights and economic rights) from the time a work is created, which means (s)he is entitled to the moral rights from the moment the work is born. In the Hungarian copyright law, there are three moral rights: the right to publication the work, ${ }^{4}$ the right to indication the author's name $^{5}$ and the right to integrity. ${ }^{6}$

Moral rights of authors are part of the general civil law personality rights. This link is confirmed by the relationship between copyright law and civil law, because the Civil Code $^{7}$ is the background of copyright law relations. Similarily to the personal rights declared in the Civil Code, the copyright law moral rights are sticking to the authors. It is followed by the rule that authors cannot assign or waive their moral rights or have these rights assigned to another person in any other manner. ${ }^{8}$ Despite the abovementioned rules, moral rights of authors are not in full compliance with general personality

\footnotetext{
1 The described study was carried out as part of the EFOP-3.6.1-16-2016-00011 "Younger and Renewing University - Innovative Knowledge City - institutional development of the University of Miskolc aiming at intelligent specialisation" project implemented in the framework of the Szechenyi 2020 program. The realization of this project is supported by the European Union, co-financed by the European Social Fund.

2 Tóth P. A közös jogkezelő szervezet által érvényesíthető szankciók köre, különös tekintettel a további jogsértéstől való eltiltás igényére. Liber Amicorum. Studia Gy. Boytha dedicata / M. Király, P. Gyertyánfy (ed.). Budapest : ELTE ÁJK Polgári Jogi Tanszék, 2004. P. 316 ; Balás P. Elemér. Szerzői jog. A magyar magánjog I. Általános rész, személyi jog / K. Szladics Károly (szerk.). Budapest: Grill Károly Könyvkiadóvállalat, 1941. P. 675; Balás P. Törvényjavaslat a szerzői jogról. Budapest : Magyar Jogászegylet Kiadása, 1947. P. 43.

Act LXXVI of 1999 on Copyright (henceforward abbreviated as - HCA).

4 HCA. $\$ 10$ : Authors decide whether their works can be published.

HCA. $\S 12$.

HCA. $\S 13$.

Act V. of 2013 on the Civil Code (henceforward abbreviated as : Civil Code).

8 HCA $\S 9$ (2).
} 
rights, because it is a significant difference, that moral rights of authors subsist after the death of the author, furthermore, the right to indication the name of the author survives the duration of copyright protection. It is also a relevant difference, that in copyright law we can not find a "general clause of personality rights", , because only the listed moral rights can be recognized, which can be found in the HCA.

According to the German Copyright Act (UrhG) ${ }^{10}$ moral rights of author are also protected (Urheberpersönlichkeitsrecht) in the §§ 12-14. Similarly to the HCA, the UrhG lists the right to publish the work (Veröffentlichungsrecht $)^{11}$, the right to designation of name (Anerkennung der Urheberschaft) ${ }^{12}$ and the right to integrity (Entstellung des Werkes) $)^{13}$. These central rules relating to moral rights are complemented with the $\S \S 25,39$ and $42 .{ }^{14}$ In the British Copyright Act (CDPA) ${ }^{15}$ moral rights can be found in Chapter IV, where it fixes the right to be identified as author or director ${ }^{16}$ and the right to object to derogatory treatment of work. ${ }^{17}$

An essential problem of moral rights is that they are highly protected due to the rules of copyright law in theory, but in practice, they are very vulnerable. This kind of vulnerability can be discovered and detected much easier in some cases and it raises serious questions of interpretation in other cases. For example, the violation of the right to indication the name of the author can be identified easier than the harming of the integrity of the work. This paradoxical situation can be justified with that exercising moral rights does not mean the overall control on the fate of the work. ${ }^{18}$ In the essay I will outline the general rules on moral rights of the author and then I will put the emphasis on the most interesting moral right: the integrity of the work. The work focuses on the Hungarian copyright law

\footnotetext{
9 Civil Code $\S 2: 42$.

10 Gesetz über Urheberrecht und verwandte Schutzrechte (Urheberrechtsgesetz), 1965 (Henceforward abbreviated - UrhG)

$11 \quad$ UrhG. $\$ 12$.

12 UrhG. $\$ 13$.

13 UrhG. § 14/

14 Grosheide W. Moral rights. Research Handbook on the Future of EU Copyright / E. Derclay (ed.). Cheltenham : Edward Elgar Publishing, 2009. P. 262.

15 Copyright, Design and Patent Act, 1988 (Henceforward abbreviated as - CDPA).

16 CDPA. Section 77.

17 CDPA. Section 80 ; See also : de Werra (2009).

18 Pogácsás A. Mire jó a szerzői jog és mire nem? Gondolatok szerző jogi "határesetekről" és tanulságaikról.: Ünnepi tanulmányok Csécsy György 65, születésnapja tiszteletére / V. Szikora Veronika, E. Török (ed.). II. Debreceni Egyetem Állam, és Jogtudományi Kar. Debrecen, 2017. P. 149.
} 
rules and in some respects, it overlooks to other European copyright law systems as well.

\section{The right to publish the work}

According to the $\S 10$ of the HCA the author shall decide whether his work may be made public. Before making the work public, any information on its substantial content may be provided for the public only subject to the author's consent. Typical platforms of publishing information are the websites, brochures, posters or press conferences.

Obviously, it does not constitute an infringement if a brochure contains a summary of the contents of an already published literary work. Therefore, from the viewpoints of copyright law it does not mean an infringement if we see an abstract from the content of the Midsummer Night's Dream, or the Gone with the wind even if the certain movie or theatrical production is recent, because these stories are known and published former as literary works.

In copyright relationships the works made for hire are frequent occurrences. According to the $\S 10$ (3) of the HCA the conclusion of a licence agreement shall imply the author's consent to the user providing information on the content of the work for the public in a manner complying with the purpose of the use. If the author and the user are in an employment relationship with each other, we shall take into consideration the $\S 30$ of the HCA, which states if the preparation of a work is the author's obligation within the scope of his/her employment, the delivery of the work is considered as approval for publication. ${ }^{19}$ So in this case, the delivery of the work is an important moment, because from this moment the employer can decide whether the work will be published or not.

The right to anonymity in the $\S 11$ of the $\mathrm{HCA}$ is the counterpart of the right to publish the work. In generally this means that the author in written form and on serious grounds - can withdraw the authorisation to make his work public or may prohibit the continued use of his work already made public, however, he is obliged to compensate any damage having occurred till the time of such statement. The exercise of the right of withdrawal is relatively rare in the legal practice. The reason can be found in the complexity of the relevant rules and in the "burdens" on the author's side. On the one hand, the Act requires conditions, which can make the margin of the author narrower. Such conditions are

\footnotetext{
19 HCA. $\S 30$ (5), first sentence.
} 
the written form, the serious ground and the obligation to compensate the damage of the user arisen in relation to the withdrawal. On the other hand, the second sentence of the $\S 11$ states that "This shall not prejudice the employer's right to exploit the work and shall not prevent, in the case of the assignment of the economic rights, the person acquiring the rights from uses based on the economic rights". According to the rules of works made for hire, we shall take into consideration that this rule does not constrain the employer's right practically, because it "only" requires to delete the author's name from the work. ${ }^{20}$ The $\S 53$ of the HCA makes further limit for the author if there is a license agreement, because it allows the termination of the license agreement, but requires a security to compensate the use for the damage.

As we saw, the Act requires a so-called "serious ground" if the author would like to withdraw the work. Such serious ground can be his/her radically changed ideology, or the serious failure of the published work. For example, Puccini decided to withdraw the Madama Butterfly after the world premier and he payed his remuneration back. ${ }^{21}$ The withdrawal was justified by the failure of the premier and the influence of rivals. ${ }^{22}$ This situation can be regarded as "serious ground". It also has to be noted that, from the viewpoints of copyright law, it means the prohibition of the continued use of the work rather than the withdrawal of make the work public. ${ }^{23}$

It is quite interesting, that the CDPA does not give concrete regulation about the right to publish the work. In the UrhG we can find this moral right, in the $\S 12$, which states that the author has the right to determine whether and how his work shall be published. The author can reserve the right to communicate or describe the content of his work to the public as long as neither the work nor the essential content or a description of the work has been published with his consent. ${ }^{24}$

\footnotetext{
20 HCA. $\S 30(5)$.

${ }^{21}$ Winkler G. Barangolás az operák világában. Budapest : Tudomány Kiadó, 2004-2006. P. 1966.

22 Budden J. Életek és művek: Puccini. Budapest : Európa Könyvkiadó, 2011. P. 276-277.

23 HCA. $\S 11$.

24 UrhG. § 12 Veröffentlichungsrecht.

(1) Der Urheber hat das Recht zu bestimmen, ob und wie sein Werk zu veröffentlichen ist.

(2) Dem Urheber ist es vorbehalten, den Inhalt seines Werkes öffentlich mitzuteilen oder zu beschreiben, solange weder das Werk noch der wesentliche Inhalt oder eine Beschreibung des Werkes mit seiner Zustimmung veröffentlicht ist.
} 


\section{The right to indicate the name of the author}

The rules of the right to indicate the name of the author in the HCA, is based on the $\S 2: 43$ of the Civil Code $^{25}$ and it is linked to the acknowledgement of the status of author. According to the $\S 12$ of the HCA, the author shall have the right to be indicated on his work or in the communication relating to his work as an author. Reference shall be made to the author in the event of including a part of his work in another work, and quoting or reviewing his work, but this can be difference regarding to the types of the works. ${ }^{26}$ The author may exercise the right to have his name indicated subject to the nature of the use and in a manner complying therewith. ${ }^{27}$ The indication of the author's name does not draw to the background nor in the event of adaptations, because if a work is the result of an adaptation - for example a movie or a theatrical or musical adaptation - the name of the original author shall be indicated on the adapted, derivative work as well. The most expressive examples for this rule are the posters and placards of a movie or dramatic works, where all the names shall be indicated, who made intellectual activity regarding to the work. As the original author's name shall be indicated on the adapted work, the name of the translator of the foreign works shall be represented. The strength of the author's name right can be reflected in the rule, that the name shall be indicated after the duration of copyright protection. ${ }^{28}$ We need to take into consideration, that in many cases, the omission of a name actually serves to cover plagiarism.

\section{The right to the integrity of the work}

The right to integrity of the work, or with other terminology, the protection of the unity of the work raises the most interpretative questions amongst moral rights.

According to the HCA "The moral rights of an author shall be considered violated by every kind of distortion and mutilation or alteration in any manner or any form of misuse of his/her work which prejudices the honour or reputation of the author". ${ }^{29}$

25 Civil Code. $\S 2: 43$ (Specific personality rights).

The following, in particular, shall be construed as violation of personality rights:

f) any violation of the right to a name.

26 Pogácsás A. Mit veszíthet egy szerző? Gondolatok a sérelemdíj szerzői jogban betöltött szerepéről. (L)Ex Cathedra et Praxis. Ünnepi Kötet Lábady Tamás 70, születésnapja alkalmából / Z. Csehi Zoltán (ed.) et al. Budapest : Pázmány Press, 2014. P. 628.

27 HCA. $\S 12(1)$.

28 HCA. $§ 14(2)$.

29 HCA. $\$ 13$. 
The protection of the integrity of the work (non-distortion) is one of the most important and elementary personal rights of authors but also it is the most complex. Faludi Gábor emphasizes ${ }^{30}$ that the problematic issues of the right to integrity can be attributed, on the one hand that the rules of international conventions are incomplete in relation to the moral rights and this lack leads to difference interpretations. On the other hand, it is complicated because it shall be applied in a wide variety of disputes. And thirdly the fact that the HCA refers specifically to the notion of honour and reputation as a yardstick for violating the right to integrity, which also raises dilemmas.

The right to integrity expresses the close relationship between the work and the author, so the basic purpose of the legal regulation can be understood: the work of the author shall be presented to the public without any distortions, or such changes, which would harm the reputation and honour of the author. The reason for this rule is that the author is adjudged on the basis of his works by both society and the profession. This situation makes the right to integrity the most sacred right - besides the abovementioned name right, because the works shall be published in the way the author created it.

The British legal terminology - where the terminology of right of respect can be used besides the right of integrity - reflects that this right includes the appreciation and respect of the author. The purpose of this rule is to prevent the dis advantageous influencing the author's social and professional adjudication by outsider people.

The unity of the work and its protection carries a double meaning, due to the word "unity". On the one hand, "unity" is intended to express what the legal norm itself seeks to achieve as well: the spirit of the work represented by the author must be prevailed in an indivisible unity. On the other hand, "unity" also means that if the change that the user introduced into the work, as a whole does not affect the overall image of the work negatively, because it does not disrupt its unity, the change will not result any infringement of the author's right. Violations of the right to integrity can range from the "simplest", everyday cases to the very complex, combined and difficult cases. Levente Tattay mentions the example for the "everyday" distortion when the editor changes the title of a newspaper article without the author's knowledge and consent and the changed title does not meet the content of the article. ${ }^{31}$ The most important and watershed

\footnotetext{
30 Faludi G. A szerzői mủ egysége védelmének egyes kérdései. Infokommunikáció és jog. 2011. № 5. P. 163.

31 Tattay L. A szellemi alkotások joga. Budapest : Szent István Társulat, 2001. P. 78.
} 
question in the Hungarian legal literature and copyright law practice is that whether the text of the HCA means that ${ }^{32}$ the harm of the aurhor's honour or reputation is a requirement for all four behaviours (distortion, mutilation, alteration, misuse) or it connects only to the alteration or misuse. ${ }^{33}$ On the basis of right to integrity, an author can act on the one hand against any distortion or mutilation of his work and, on the other hand, against any alteration or defamation which is detrimental to his honor or reputation. ${ }^{34}$ Honour means the social status of the person, where the person's own will is the starting point for what (s)he personally consider valuable. ${ }^{35}$ Reputation means the social, public and economic awareness of the person. ${ }^{36}$

The protection of the unity of the work must be identified with the concept of completeness and sacredness. This does not necessarily mean the physical unity of the work, but rather it is intended to ensure the spiritual unity, the integrity of the message of the work. The purpose of integrity protects the work as a whole, including its title, but it also important that it shall not be limited to those works which are materially embodied in copies. ${ }^{37}$

The actual enforcement of the very abstract general rule of integrity shall be applied in a different way in the variant forms of works. ${ }^{38}$ This can be reflected in the special rules of the $\mathrm{HCA}^{39}$, in the judicial practice and in the interpretations of The Council of Copyright Experts (in Hungarian: SZJSZT). ${ }^{40}$ The HCA also gives special rules on the performers' integrity right as well. ${ }^{41}$

\footnotetext{
32 Faludi. Op. cit. P. 165.

33 This question arises in the judicial practice as well. See e.g. Case № P.23.377/2009/34, and Case № Pfv.IV.21.744/2007/6.

34 See the critical interpretation of this rule e.g. A szerzöi mü egysége védelmének egyes kérdései / G. Faludi. Infokommunikáció és jog. 2011. № 5 ; Grad-Gyenge A. Első oldal. Infokommunikáció és jog. 2013. № 3. URL: http://www.infojog.hu/szam/54 ; Gyertyánfy P. A szerzői jog bírói gyakorlata 2006-tól: a védelem tárgya és a mủ egysége. Iparjogvédelmi és Szerzői Jogi Szemle. 2012. № 4.

35 Barzó T. A személyiségi jogok. Új Magyar Polgári Jog (I-VIII) Tankönyv I. Általános tanok és Személyek joga / G. Bíró (ed.). Miskolc : Novotni Kiadó, 2013. P. 250.

36 Barzó. Op. cit. P. 251.

37 Nagykommentár a szerzői jogi törvényhez / P. Gyertyánfy (ed.). Budapest : Wolters Kluwer, 2014. P. 138.

38 Kézikönyv a szerzői jog érvényesítéséhez. ProArt Szövetség a Szerzői Jogokért. 2013. P. 51.

39 For example: the HCA gives special rights in relation to architectural works, fine arts or performers.

40 For example: SzJSzT 2013/02, SzJSzT 2010/18, SzJSzT 2008/20, SzJSzT 2010/17, SzJSzT 2009/04, SzJSzT 2003/30.

41 HCA $§ 75(2)$
} 
In connection with the rule of integrity the most important consideration is that this right may be different interpretations in each types of works. In a dispute over the interpretation of integrity, when we shall answer the question whether the unity of the work was harmed or not, we can only give a correct answer by considering all aspects of the concrete case.

The right to integrity is emphasized in other European courties as well. Jacques de Werra thinks that the German and French copyright law provide for the most protective regimes for moral rights and specifically for the right of integrity. ${ }^{42}$

Sophia Sepperer points out that the $\S \S 39$ and 62 of the UrhG restrict the right to integrity. ${ }^{43}$ The German copyright law applies a special rule to protect the integrity of authors ${ }^{44}$ and performers ${ }^{45}$ and does not prohibit the modifications generally to the latter, but only protects them from such changes that have a negative impact on their reputation and honour.

The French copyright law $^{46}$ also deals with moral rights. ${ }^{47}$ As we mentioned it before, in the French copyright system moral rights and especially the right to integrity have strong roots. ${ }^{48}$ According to the Article 121-1 of the CPI author shall enjoy the right to respect for his name, his authorship and his work. Moreover the Act adds that "Whatever the marriage arrangements and on pain of nullity of any clause to the contrary contained in a marriage contract, the right to disclose a work, to lay down the conditions for exploiting it and for defending its integrity shall remain vested in the spouse who is the author or in the spouse to whom such rights have been transmitted". ${ }^{49}$ This latter rule also reflects the importance of the unity of the work in every legal relationships.

In the CDPA we can also find the integrity rule. According to the Section 80 of the CDPA, the author of a copyright literary, dramatic, musical or artistic work, and the director of a copyright film, has the right

${ }_{42}$ De Werra J. The moral right of integrity. Research Handbook on the Future of EU Copyright I E. Derclay (ed.). Cheltenham : Edward Elgar Publishing, 2009. P. 279.

43 Sepperer S. Der Integritätsschutz der Bühneninszenierung. Berlin, 2015. P. 60.

44 UrhG. $§ 14$.

45 UrhG. $§ 75$.

46 Code de la propriété intellectuelle (Law № 92-597 of July 1, 1992) (hence forward abbreviated - CPI).

47 CPI. Articles L121-1 to L121-9.

48 About the historicl roots see : From the Providence of Kings to Copyrighted Things (And French Moral Rights) / C. Peeler. Indiana International \& Comparative Law Review. 1999. Vol. 2. P. 423-456 ; Ginsburg J. Tale of Two Copyrights: Literary Property in Revolutionary France and America. Tulane Law Review. 1990. № 5. P. 991-1031.

49 CPI. Article L121-9. 
not to have his work subjected to derogatory treatment. ${ }^{50}$ The Act also adds that treatment of a work means any addition to, deletion from or alteration to or adaptation of the work, other than a translation of a literary or dramatic work, or an arrangement or transcription of a musical work involving no more than a change of key or register. ${ }^{51}$ Due to the Act the treatment of a work is derogatory if it amounts to distortion or mutilation of the work or is otherwise prejudicial to the honour or reputation of the author or director. ${ }^{52}$

\subsection{The right to integrity in literary and music works}

Literary works can be regarded as the core of copyright. The spread of illicit copies of literary works was the direct causes of the recognition of copyright law because the invention of Gutenberg boosted the making of copies. "A book is not simply a medium for literary content. First and foremost, it shapes the basic categories for describing texts and their qualities, such as cohesion, integrity, immutability, individual character, authorship, and so on". ${ }^{53}$

The infringement of right to integrity of a literary work can be observed easily in some cases. For example, if a press publishes the work according to a semi-finished manuscript, or because of an editing error it skips a few chapters from the complete work, it grounds the infringement. It is another question that the author and the press are in a contract relationship as well, so in such cases the press breaches the contract also and shall pay the damages due to the rules of contractual liability. I think that in a case, where the press publishes the semi-finished manuscript the infringement of right to integrity shall be presumed. ${ }^{54}$

The copyright issues of music can be regarded as one of the evergreen topics of copyright law, so the same is true in relation to the right to integrity of music as well. "Music, more than any other vehicle of culture, collapses the gap that seperates idea from expression". ${ }^{55}$ The questions

\footnotetext{
50 CDPA. Section 80 (1).

51 CDPA. Section 80 (2).

52 CDPA. Section 80 (3).

53 Palęcka A., Jakubowiak M. Who Needs the Book? Copyright in the Late Print Epoch. English Edition, 2017. P. 210.

54 We would like to note for the sake of comleteness, that this behaviour also could constitute the harm of another moral right as well, the right to publication the work, because the author has the right to decide when (s)he would like to publish the work.

55 Vaidhyanathan S. Copyrights and copywrongs. The rise of Intellectual Property and How It Threatens Creativity. New York ; London : New York University Press, 2001. P. 117.
} 
of the right to integrity in relation to music works can arise mostly in adaptations, arrangements. In a concrete case the SZJSZT pointed out that the performances of musical compositions necessarily differ from each other, as the personality and style of the performer appear during the playing of the work. In the field of pop music this freedom of performance is even greater than in classical music. The SZJSZT added that if the changing of the end of a music during the arrangement does not change the whole song substantially, we cannot talk about a moral right infringement. ${ }^{56}$ According to the SZJSZT, distortion means such gross changes that alter the work in a way that is fundamentally offensive to the listener, the viewer, and the sensor in general. ${ }^{57}$ In another case,${ }^{58}$ the court high lightened that changing, distorting or mutilating the essential features of the work without the author's permission, regardless of any further adverse consequences, can violate the author's right to the integrity of the work. In the concrete case, the unauthorized shortening, and reworking the music and deleting the lyrics of the author's work is a distortion or mutilation of the essence of the work which infringes the author's moral right. In an other case, an unauthorized adaptation of the work was used in a theme song of a reality show. The SZJSZT emphasized that the significant rewriting of the lyrics of the work, in addition to being so distant from the original thought, is clearly a distortion of the work and violates the composer's and the lyricist's moral rights..$^{59}$

\subsection{The right to integrity and dramatic works}

The right to integrity can often be harmed due to a theatrical adaptation, but there are only few published legal disputes in relation to the right to integrity. ${ }^{60}$ This situation can be traced back to three reasons, which can limit the real enforceability of the harm of the right to integrity. On the one hand it can be observed, that such radical interventions into the spirit of the original work are often done for works which term of protection has already been expired. On the other hand, disputes between the theatre and the author are often closed with a perpetual agreement. Thirdly, the provisions of the Act themselves can limit the reference to the protection

\footnotetext{
56 SZJSZT 18/10.

57 SZJSZT 18/10.

58 Curia, № 21744/2007/6.

59 SZJSZT. 02/13

${ }^{60}$ See in details : Sápi E. A színpadi mủvek szerzői joga. Budapest : Patronicium Kiadó, 2019. P. $145-160$.
} 
of the integrity of the work. For these reasons, it is often difficult to "catch" the harm of the integrity of the given work in the stage, even if it is felt that the original piece has barely stayed on the stage. As we mentioned it former, the unity, integrity of the work covers the physical unit and the unit of the content of the work. However it cannot be stated with certainly that the disintegration of the physical unity of a work would result always an infringement of the integrity. ${ }^{61}$ The mere fact that the intermission of the play, for various technical reasons, ${ }^{62}$ is not put to the exact place where the author of the original work intended, does not mean that the integrity of the work is definitely gets hurt. Consequently, we shall regard the play as a complete unit and it would be unreasonable for such a rigid application of the rule would damage the integrity of the work. At the same time, it cannot be completely said that the disintegration of the physical unit would never constitute a breach of integrity.

During theatrical performances we can see at several times that the original features and original spirit of the work is fading on the stage or moreover it might appear unrecognizable. The German jurisprudence is overflowed in stage productions where the original work is hardly met by the new stage version. ${ }^{63}$

The most important question in relation to this topic is, which are the most common examples of the infringement of integrity right of dramatic works. As we mentioned it before it is quite hard task to list the cases of infringement of right to integrity because all aspects of the certain case shall be taking into consideration. If we would like to outline the most common examples of the infringement of unity of the work, the following cases can be examples: distortion and misrepresentation of the content or the message of the work, deleting important scenes while others are exaggerated, if these changes result injurious effect to the author. For example, if the theatre performs the work in a way, where the original script is radically changed, and the political storyline is highlighted at a disadvantage of the lovestory, this can constitute the infringement. ${ }^{64}$

\footnotetext{
${ }^{61}$ Gyertyánfy. Op. cit. P. 136.

${ }^{62}$ For example, if it may take longer for the stage to be reordered or for the characters to be changed.

${ }^{63}$ Infamous cases for example: Baal (LG München I - 21 O 1686/15), Götterdämmerung (OLG Frankfurt, 04.12.1975-6 U 156/75), or Csárdásfürstin (LG Leipzig, Urteil v. 23.2.2000, ZUM 2000).

${ }^{64}$ Gyenge A. Zeneművek átdolgozása a szerzői jogban. Iparjogvédelmi és Szerzői Jogi Szemle. 2002. № 3.
} 
It also can be infringing if the theatre changes the scenery design, the decoration of the performance without the consent of the scenery designer, and it is harmful for the reputation and honour of the designer, ${ }^{65}$ because (s)he is entitled to copyright due to the HCA. The German legal literature on the theatrical dimension of the right to integrity emphasizes that the author is not only interested in receiving his remuneration, but also in communicating his work to the public in the way he wrote it. Because of this, authors or their heirs, often require a controlling right in the performance contract to oversee and protect the integrity of the work on the stage. Within its scope, the author can influence the choice of director, actor or scenery designer. ${ }^{66}$

\subsection{The right to integrity in relation to architectural works and fine arts}

The Act regulates the right to integrity in relation to the architectural works or technical structures in special rules. According to the $\S 67$ of the HCA, any alteration of the design of an architectural work or technical structure that is made without the author's authorization and influences the appearance, the intended use, or the operation of the work shall be regarded as an unauthorized alteration of the work. ${ }^{67}$ There are many specialities of copyright law in relation to architectural works which can effect the right to integrity as well. Such specialities can be found in the conflicts between the rights and interests of owner of the building and of the author. ${ }^{68}$ Another important speciality of copyright situation of architectural works is the fact, that the architectural work is not build by the author, who created the plan but by another person, the constructor. ${ }^{69}$

It is also important, that there are differences between the content of the $\S \S 13$ and 67 of the HCA, which can result interpretation problems. ${ }^{70}$ Another aspects which shall be emphasized that buildings, architectural

\footnotetext{
$65 \quad$ SZJSZT. 39/07.

${ }^{66}$ Schack H. Urheber - und Urhebervertragsrecht. 5 Auflage. Tübingen : Mohr Siebeck, 2010. P. 559.

67 HCA. $\$ 67(1)$.

68 See in details : Bertoni A., Montagnani M. Public architectural art and its spirits of instability. Academia.edu. P. 7-17. URL: https://www.academia.edu/11828224/Public_architectural_art_and_ its_spirits_of_instability.

69 Barta J. Az építészeti és műszaki alkotások és terveiket érintő egyes szerzői jogi kérdések a 21. századi Magyarországon. Acta Universitatis Sapientiae. Legal Studies. 2017. № 2. P. 230.

70 Barta J. A tervezői tevékenység komplex bemutatása, valamint az építészeti, műszaki alkotások és tervek szerzői jogvédelme. Budapest : Patrociniium Kiadó, 2018, 325 p.
} 
works are so-called functional works. It means that the practical utilisation of the work is often more important than the artistical aspects, ${ }^{71}$ which can be the limit of moral rights as well. Another interesting point of the topic is that the copyright law has no effect in the case of demolition of the building, because this decision belongs to the ownership right of the proprietor. ${ }^{72}$

In many cases, the court should interpret the content of the right to integrity when moving architectural works and monuments from one location to another. In a concrete case, the court emphasized, that "The relocation of a work obviously affects the integrity of the work and its message, so it covers the rule of 13. \& of the HCA, but it shall be considered, that according to the 13. $\S$ any alteration to a work is unlawful if it damages the honour or reputation of the author". ${ }^{73}$ In another decision, the court high lightened, that "The owner of the building has the right to rebuild the building that (s)he owns, to change its appearance, architectural design, purpose or to demolish it. Reconstruction of a building due to the proper exercise of the owner's right shall not result the infringement of the designer's (author) copyright". ${ }^{74}$ It is also important, that according to the judicial practice, it is not a misuse if the author refuses his/her subsequently requested consent in the event of unauthorized modification of the building, which is a copyrighted work. ${ }^{75}$ Of course the author can authorize some modifications, rebuilding's of the works, but it shall be fixed in the contract. ${ }^{76}$

The Act gives special regulation on the right to integrity for architectural works only, but we cannot find any special integrity right to fine arts. This results that the general rule, the $\S 13$ shall be applied for fine arts as well. The term "fine art" refers to an art form practised mainly for its aesthetic value and its beauty rather than its functional value. Fine art is covering drawing, painting, printmaking, and sculpture. Problems of right to integrity of fine arts seems less relevant at first sight, because it is common that only one original piece is existing, and the adaptation of fine arts - which is a really sensitive point of unity of the work - is rarer. At the same time, it is true that fine art can be a subject of unlawful

\footnotetext{
71 Barta. Op. cit. 2018. P. 330.

72 Barta. Op. Cit. 2018. P. 345.

73 Court of Pest County. P. 23.377/2009/34.

74 BDT. 2010. 2329.

75 BDT. 2008. 1756.

76 Csillag G. Az építészeti alkotások szerzői jogi oltalma. Budapest : Építésügyi Tájékoztatási központ, 1987. P. 89.
} 
replica frequently. It shall be mentioned that a "mere" replica of a painting or a sculpture will not result the infringement of the right to integrity, but it will ground a general copyright infringement, because of the illicit copy of the work. However, the unity of the work can be harmed for example in the case, if the artwork is photographed and it manipulated with digital technique on the photo. If this manipulated photo of the painting or sculpture is harmful for the honour or reputation of the author, it can constitute the infringement of the unity of the work.

\section{CONCLUSIONS}

The right to integrity is intended to protect the moral and intellectual integrity of the author and his work. Although it is intended to protect the individuality of the author, whose thoughts and personality appears in the work, but this right is not unlimited. ${ }^{77}$ On the one hand, the author may make a statement authorizing the change of his work and on the other hand it may be limited by the provisions of the law. But, according to the HCA, authors cannot waive his or her moral rights. ${ }^{78}$ This results that the author cannot give such authorization of licence in which (s)he allows to infringe the moral rights.

It can be also an interesting question that could the author's successor define such requirements in connection with the adaptation or reproduction of the original work which the author did not define and could the successor claim for an infringement of right to integrity if the user would "breach" the conditions of the successor? I think the successor cannot claim for infringement in this situation. The right to integrity shall be interpreted in the way that it shall stick to the personality of the author and the successor is not entitled to "create" a new unity, new integrity for the work. It is only the author, who knows the proper content and unit of his/her work in which (s)he intends to publish the work, so such rules can only stick to the author not to the successor. It is right to guard over the right of integrity of the author, but the inheritance of the right to integrity to the copyright successor is not the original purpose of this right.

It is also worth to talking about the philosophical aspects of the right to integrity in addition to the aboementioned practical issues. In the AngloSaxon legal literature, some authors emphasize that the right to integrity can be traced back to the theories of Walter Benjamin, Bruno Latour and Adam

77 Pogácsás. Op. cit. 2018. P. 335.

78 HCA. $\$ 9$ (2). 
Lowe. ${ }^{79}$ The conception of Benjamin refers to the "aura of the work" 80 , while Latour and Lowe enhance the "trajectory of work". According to Walter Benjamin, the "aura of the work" means that the work loses something of its original value with each use, so each use contributes to the fading of the original work. In contrast, "trajectory theory" emphasizes that every work goes through an evolution and this development, or "trajectory", is particularly true for theatrical productions, because the author hopes that his work will go through the entire carrier ladder. Luke McDonagh analysis both theories in relation to dramatic works in the light of the right to integrity, but it can be applicable to all of the artworks as well. So, McDonagh explains that theatrical authors seek to protect the integrity of the work and rely on $i^{81}$ because they fear that the public will not know the true content of the work. ${ }^{82}$ This kind of approach converges to the "aura of the work". In the light the "trajectory" aspect, McDonagh adds that in the case of dramatic works there are three stages that determine their careers and ultimately determine the work itself. According to this, we can talk about debut, exceptional and classic works. The debut period means the first few performances of the work, its initial stage. A play becomes exceptional when the work is performed several times and by different theatres. And classic plays can be considered when the work becomes an accepted and integral part of the theatrical repertoire. ${ }^{83}$ I think that the joining of the two theories is the best solution. Every dramatic work has its "trajectory", most of them reaches the exceptional stage, and some of them become classic. However, in my point of view it is not necessarily true that the original work is fading because of its frequent use. It can be happening that people read or listen the original work (whether it is a literary, dramatic or a musical work) because the derivative production is well received.

\section{SUMMARY}

The essay shows the most important regulations on moral rights primarily in the Hungarian copyright law, with a brief outlook to the German, British and French copyright law regimes. In the article I put the emphasis on the right to integrity, which is the most complex moral

\footnotetext{
79 McDonagh L. Plays, Performances and Power Struggles - Examining Copyright's 'Integrity' in the Field of Theatre. Modern Law Review. 2014. № 4. P. 534.

${ }_{80}$ Benjamin W. The Work of Art in the Age of Its Technological Reproducibility. The original title : Das Kunstwerk im Zeitalter seiner technischen Reproduzierbarkeit, 1936.

81 CDPA. Section 80.

82 McDonagh. Op. cit. P. 534.

${ }^{83}$ McDonagh. Op. cit. P. 534-535.
} 
right. I present how the right to integrity can show its different faces in relation to dramatic works, architectural works, works of fine arts, literary works and music works. As it can be seen in the article, this right is prevailing in different ways in relation to the different forms of copyright works. This situation can raise questions of interpretation and problems in the practical enforcement of the right, because in most of the European countries there are no separate regulations for the integrity of all kind of works. It is common that there is one general rule about the right to integrity and this is supplemented with another one or two integrity rules for example about performers' right or architectural works, as we see it in the Hungarian copyright law as well. At the same time, it is important to emphasize that there is no need to have separate integrity rules for all the types of work, because it would make the essence and spirit of integrity unserious and in the same time rigid. Therefore, it is not a real problem if a copyright act provides only one rule about the protection of the unity of the work, if it can be interpreted adequately in the judicial practice to serve its original purpose: everyone shall respect the author and the spirit, the message of the work.

\section{REFERENCES}

1. Balás P. Elemér. Szerzői jog. A magyar magánjog I. Általános rész, személyi jog / K. Szladics Károly (szerk.). Budapest: Grill Károly Könyvkiadóvállalat, 1941.

2. Balás P. Törvényjavaslat a szerzői jogról. Budapest: Magyar Jogászegylet Kiadása, 1947.

3. Barta J. A tervezői tevékenység komplex bemutatása, valamint az építészeti, műszaki alkotások és tervek szerzői jogvédelme. Budapest : Patrociniium Kiadó, 2018.

4. Barta J. Az építészeti és müszaki alkotások és terveiket érintő egyes szerzői jogi kérdések a 21. századi Magyarországon. Acta Universitatis Sapientiae. Legal Studies. 2017. № 2.

5. Barta J. Építészeti alkotások szerzői jogi védelme és a gazdasági reklámozás némely összefüggései megtörtént esetek kapcsán. Iparjogvédelmi és Szerzői Jogi Szemle. 2011. № 6.

6. Barzó T. A személyiségi jogok. Új Magyar Polgári Jog (I-VIII) Tankönyv I. Általános tanok és Személyek joga / G. Bíró (ed.). Miskolc : Novotni Kiadó, 2013.

7. Benjamin W. The Work of Art in the Age of Its Technological Reproducibility. The original title: Das Kunstwerk im Zeitalter seiner technischen Reproduzierbarkeit, 1936. 
8. Bertoni A., Montagnani M. Public architectural art and its spirits ofinstability.Academia.edu.P.7-17.URL:https://www.academia.edu/11828224/ Public_architectural_art_and_its_spirits_of_instability.

9. Budden J. Életek és művek: Puccini. Budapest : Európa Könyvkiadó, 2011.

10. Csécsy G. A szellemi alkotások joga. Miskolc : Novotni Kiadó, 2007.

11. Csillag G. Az épitészeti alkotások szerzői jogi oltalma. Budapest: Építésügyi Tájékoztatási központ, 1987.

12. Werra J. De. The moral right of integrity. Research Handbook on the Future of EU Copyright / E. Derclay (szerk.). Cheltenham : Edward Elgar Publishing, 2009. P. 267-285.

13. Faludi G. A szerzői mü egysége védelmének egyes kérdései. Infokommunikáció és jog. 2011. № 5.

14. Ginsburg J. Tale of Two Copyrights: Literary Property in Revolutionary France and America. Tulane Law Review. 1990. № 5. P. 991-1031.

15. Grad-Gyenge A. Első oldal. Infokommunikáció és jog. 2013. № 3. URL: http://www.infojog.hu/szam/54.

16. Grosheide W. Moral rights. Research Handbook on the Future of EU Copyright / E. Derclay (ed.). Cheltenham : Edward Elgar Publishing, 2009.

17. Gyenge A. Zenemüvek átdolgozása a szerzői jogban. Iparjogvédelmi és Szerzöi Jogi Szemle. 2002. № 3.

18. Nagykommentár a szerzői jogi törvényhez / P. Gyertyánfy (ed.). Budapest : Wolters Kluwer, 2014.

19. Gyertyánfy P. A szerzői jog bírói gyakorlata 2006-tól: a védelem tárgya és a mü egysége. Iparjogvédelmi és Szerzöi Jogi Szemle. 2012. № 4.

20. Kézikönyv a szerzői jog érvényesítéséhez. ProArt Szövetség a Szerzői Jogokért. 2013.

21. McDonagh L. Plays, Performances and Power Struggles - Examining Copyright's "Integrity” in the Field of Theatre. Modern Law Review. 2014. № 4.

22. Palęcka A., Jakubowiak M. Who Needs the Book? Copyright in the Late Print Epoch. English Edition, 2017.

23. Peeler C. From the Providence of Kings to Copyrighted Things (And French Moral Rights). Indiana International \& Comparative Law Review. 1999. Vol. 2.

24. Pogácsás A. A digitalis mü integritás védelmének aktuális kérdései. LiberAmicorum. Studia G. FaludiDedicata / A. Grad-Gyenge, E. Kabai Eszter, A. Menyhárd (ed.). ELTE. Állam-és Jogtudományi Kar. Budapest, 2018.

25. Pogácsás A. Mire jó a szerzői jog és mire nem? Gondolatok szerző jogi "határesetekről" és tanulságaikról. Ünnepi tanulmányok Csécsy György 65, születésnapja tiszteletére / V. Szikora E. Török (ed.). II. Debreceni Egyetem Állam, és Jogtudományi Kar. Debrecen, 2017. 
26. Pogácsás A. Mit veszíthet egy szerző? Gondolatok a sérelemdíj szerzői jogban betöltött szerepéröl. (L)Ex Cathedra et Praxis. Ünnepi Kötet Lábady Tamás 70, születésnapja alkalmából / Z. Csehi Zoltán (ed.) et al. Budapest : Pázmány Press, 2014.

27. Sápi E. A színpadi művek szerzői joga. Budapest : Patronicium Kiadó, 2019.

28. Schack H. Urheber - und Urhebervertragsrecht. 5. Auflage. Tübingen : Mohr Siebeck, 2010.

29. Sepperer S. Der Integritätsschutz der Bühneninszenierung. Berlin, 2015. 2001.

30. Tattay L. A szellemi alkotások joga. Budapest : Szent István Társulat,

31. Tóth P. A közös jogkezelő szervezet által érvényesíthető szankciók köre, különös tekintettel a további jogsértéstöl való eltiltás igényére. Liber Amicorum. Studia Gy. Boytha dedicata / M. Király, P. Gyertyánfy (ed.). ELTE ÁJK Polgári Jogi Tanszék. Budapest, 2004.

32. Vaidhyanathan S. Copyrights and copywrongs. The rise of Intellectual Property and How It Threatens Creativity. New York; London: New York University Press, 2001.

33. Winkler G. Barangolás az operák világában. Budapest: Tudomány Kiadó, 2004-2006.

Information about author:

Sápi Edit, Ph. D., Research Fellow at the Civil Law Department Institution of Civil Law Faculty of Law University of Miskolc Egyetemváros-Miskolc, 3515, Hungary

DOI https://doi.org/10.30525/978-9934-588-43-3/1.9 